\title{
PERŁA BAROKU ODZYSKALA BLASK. SPRAWOZDANIE $Z$ KONFERENCJI NAUKOWEJ „NAJWIĘKSZE WYZWANIE REWITALIZACYJNE XXI WIEKU. KOŚCIÓŁ OO. FRANCISZKANÓW W ZAMOŚCIU", 25 WRZEŚNIA 2021 R.
}

Zamość - wyjątkowe miasto, nazywane idealnym, powołane do życia w XVI wieku dzięki zamysłowi kanclerza i hetmana wielkiego koronnego Jana Zamoyskiego - odzyskał niedawno barokową perłę. 17 września 2021 r., o godzinie 17, nastąpiło uroczyste poświęcenie odrestaurowanego kościoła oo. Franciszkanów pw. Zwiastowania NMP - największej barokowej świątyni na terenach Rzeczypospolitej w XVII wieku, budową której kierował inżynier wojskowy Jan Michał Link, fundatorem zaś był drugi ordynat Tomasz Zamoyski i jego żona Katarzyna z Ostrogskich.

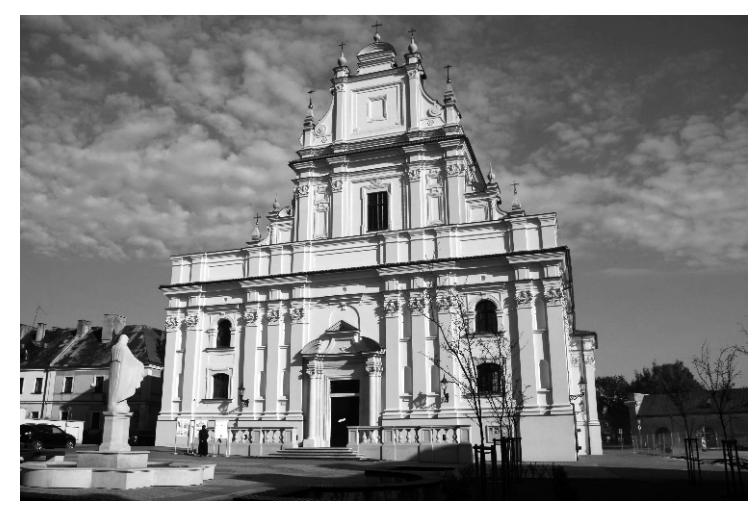

I1. 1. Zachodnia fasada kościoła oo. Franciszkanów w Zamościu odzyskała swój majestatyczny wygląd. Na placu przed wejściem stoi figura Matki Bożej Niepokalanej.

Fot. Ewelina Lilia Polańska

* Ewelina Lilia Polańska - dr nauk o sztuce; mgr historii sztuki, historii oraz filologii polskiej; wykładowca Akademii Zamojskiej w Zamościu

e-mail: ewelinalilia@wp.pl

https://orcid.org/0000-0003-2960-621X 
Kościół doświadczył burzliwych i trudnych dziejów. W drugiej połowie XVIII stulecia zaborcze władze austriackie zdecydowały o kasacie zakonu, ostatnią mszę świętą odprawiono w 1794 r., potem na długie lata budynek pozbawiono funkcji sakralnych, zmieniając go na szpital wojskowy, skład zboża, kancelarię wojskową. W XIX wieku rosyjski zaborca kontynuował dewastację świątyni, zburzono wówczas wysokie szczyty, obniżono dach nad nawą główną, zniszczono wiele cennych detali architektonicznych, wnętrze przebudowano i zmieniono na koszary. Po odzyskaniu przez Polskę niepodległości w historycznych murach mieściło się m.in. kino, liceum.

Dopiero w 1994 r., po 200 latach nieobecności, do Zamościa powrócili franciszkanie. Po latach starań, we wrześniu 2017 r. rozpoczął się kilkuletni proces rewitalizacji tego wyjątkowego dzieła polskiej architektury sakralnej. Dziś świątynia odzyskała swój blask i dumnie góruje nad panoramą miasta.

Z tej wyjątkowej okazji, w sobotę, 25 września 2021 r. w gościnnych progach Muzeum Zamojskiego odbyła się konferencja naukowa poświęcona tej niezwykłej budowli pt. „Największe wyzwanie rewitalizacyjne XXI wieku. Kościół oo. Franciszkanów w Zamościu”. Organizatorem było Koło Przewodników Terenowych PTTK o/Zamość im. Róży i Jana Zamoyskich, świętujące jubileusz 60-lecia. Konferencji przewodniczył dyrektor Muzeum Zamojskiego Andrzej Urbański. Obrady zaszczyciło swoją obecnością wielu znakomitych gości, wśród nich prezydent miasta Andrzej Wnuk, który jako pierwszy zabrał głos.

Wystąpienia konferencyjne rozpoczęła prezes Koła Przewodników Maria Rzeźniak, która przedstawiła bogatą historię działalności Koła, zrzeszającego kilkudziesięcioosobową grupę przewodników. W swoim wystąpieniu podkreślała, że przewodnicy zamojscy z zaangażowaniem pogłębiają wiedzę, później przekazywaną turystom, podczas dodatkowych kursów, szkoleń, wyjazdów terenowych czy sesji naukowych i kongresów. Tylko w latach 2010-2020 Koło zorganizowało dla kadry przewodnickiej 175 szkoleń obejmujących różnorodne spektrum tematyczne, zaś na stronie internetowej (www.przewodnicyzamosc.pl) w ciągu siedmiu ostatnich lat ukazało się 220 artykułów.

Następnie o. dr Andrzej Zalewski, gwardian i proboszcz parafii pw. Zwiastowania NMP w Zamościu, przybliżył losy i zakres rewitalizacji największego XVII-wiecznego barokowego kościoła w Polsce. Wskazał, że ta perła architektoniczna polskiego baroku po wielu dewastacjach, przebudowach i dostosowywaniu do różnych funkcji prawie całkowicie zatraciła pierwotny charakter i formę architektury sakralnej, stąd zakres odbudowy był rozległym przedsięwzięciem. Przypomniał, że część prac przygotowujących rewitalizację świątyni została wykonana dzięki zabiegom nieżyjącego proboszcza o. Bruna Kalinowskiego. Jednakże dopiero po latach starań i przygotowań, pod przewodnictwem o. dra A. Zalewskiego, kościół otrzymał dofinansowanie na przeprowadzenie prac konserwatorskich i przywrócenie historycznej formy. Całkowita wartość projektu wyniosła blisko $28 \mathrm{mln}$ zł. Dzieło odbudowy rozpoczęło się jesienią 2017 r. Proboszcz parafii opowiadał również o trudnościach i nieprzywidzianych sytuacjach podczas całego procesu. Świą- 
tynia, z Bożą i ludzką pomocą, jak podkreślał ks. Zalewski, podźwignęła się z ruin jako „symbol nieugiętości i dumy narodu polskiego i mieszkańców hetmańskiego grodu".

Etapy przygotowania projektu i jego realizację zaprezentował architekt Sebastian Ćwierz - autor projektu remontu i rekonstrukcji zamojskiego kościoła Franciszkanów. Pokazał początkową wizualizację rekonstrukcji bryły i wnętrza, zebraną dokumentację ikonograficzną potrzebną do odtworzenia pierwotnego wyglądu, plany architektoniczne. Opowiedział o problemach pojawiających się podczas tego przedsięwzięcia, pomysłach dotyczących materiałów, kwestii użytkowych (jak np. ogrzewanie) i zastosowanych rozwiązaniach. Zdradził również, że pomysł geometrycznego rozplanowania terenu przed fasadą zachodnią świątyni zaczerpnął z XVI-wiecznego traktatu swego imiennika, Sebastiana Serlia, włoskiego architekta, malarza i teoretyka architektury.

Kolejny prelegent Tomasz Bębenek - organista, zrelacjonował skomplikowany, ale interesujący proces budowy organów w odrestaurowanym XVII-wiecznym kościele Franciszkanów. Muzyka, obok słowa, jest ważnym elementem liturgii, dlatego w zabytkowych murach nie mogło zabraknąć organów piszczałkowych. Wykonane zostały w pracowni firmy Zych Zakłady Organowe w Wołominie. Ich montaż trwał 3 tygodnie. Organy mają 36 głosów, składają się z ponad 2000 piszczałek, posiadają symfoniczne brzmienie. Referent zwrócił uwagę, że są to organy romantyczne, nie barokowe, tak by można było wykonywać na nich kompozycje organowe wszystkich epok: począwszy od renesansu, poprzez barok, klasycyzm oraz muzykę XIX i XX wieku. Instrument jest jednym z największych w regionie, ubogaca już liturgię, a także rozbrzmiewa podczas koncertów organowych.

Prace budowlano-konserwatorskie objęły nie tylko bryłę, wnętrze, ale także zabytkowe krypty pod kościołem Franciszkanów, które zaaranżowano jako przestrzeń muzealną i edukacyjną. Jednym z wiodących wątków ekspozycji jest fascynująca obyczajowość polska związana z pochówkami w dobie nowożytnej, dlatego też tematem wykładu dr Eweliny Lilii Polańskiej był ceremoniał pogrzebowy (pompa funebris) w Rzeczypospolitej w XVII i XVIII wieku. Prelegentka nakreśliwszy tło historyczne, społeczne, filozoficzne i literackie doby baroku, zaprezentowała niezwykłość polskiej kultury funeralnej. Ceremonia pogrzebowa stawała się swoistym theatrum, łączącym różne środki wyrazu - począwszy od warstwy słownej kazań, gestów obrzędów, przez muzykę żałobną, aż po okazałą architekturę okazjonalną i plastyczne formy dekoracji trumny i świątyni. Centralny punkt castrum doloris stanowił „konterfekt osoby nieboszczykowej”. E. Polańska podkreśliła unikatowość na skalę światową polskiego portretu trumiennego, stanowiącego skarb kultury sarmackiej, specyficzne i nigdzie indziej nieznane w kulturze europejskiej zjawisko, będące oryginalnym wytworem Rzeczypospolitej Obojga Narodów. 


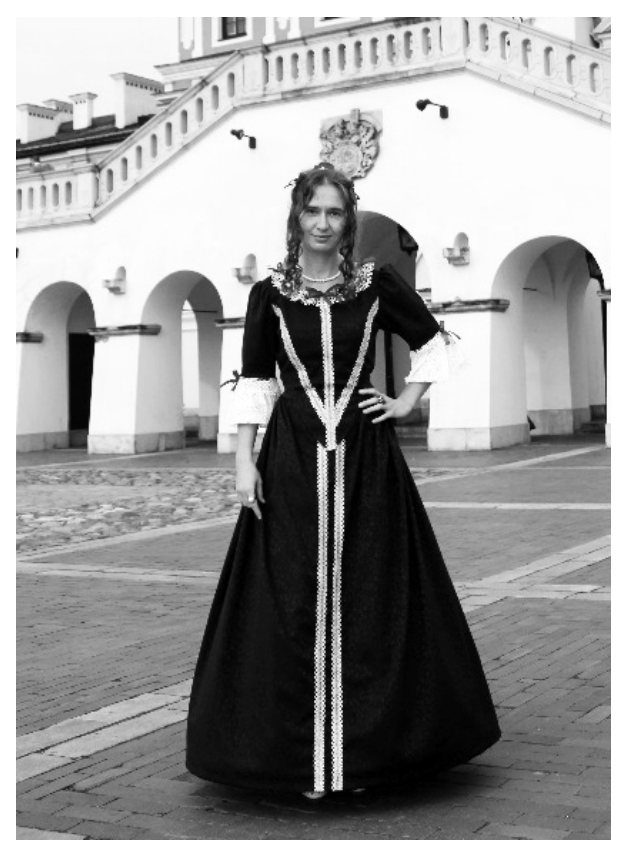

Il. 2. Dr Ewelina Polańska przybliżyła uczestnikom epokę baroku także poprzez nawiązującą do XVII wieku suknię.

Fot. Józef Polański

Ostatni przemawiający, dr inż. arch. Krzysztof Janus z Politechniki Lubelskiej, przybliżył zagadnienie ważnej dla Zamościa renowacji historycznego gmachu Akademii Zamojskiej, z którą w ciągu wieków związani byli franciszkanie, pełniący funkcje profesorów teologii we wszechnicy powołanej do życia przez założyciela miasta - wielkiego admiratora nauki. K. Janus zaprezentował fotografie i omówił odkryte podczas prac remontowych dwa pomieszczenia (dawne kaplice) ozdobione XVIII-wiecznymi polichromiami. Dotychczas udało się zidentyfikować kilkanaście scen związanych z życiem i cudami św. Jana Kantego - XV-wiecznego wykładowcy krakowskiego uniwersytetu, który od 1702 r. był patronem zamojskiej akademii.

Po zakończeniu części wykładowej, po południu, uczestnicy konferencji mogli osobiście udać się do podziemi kościoła, gdzie oglądali zabytki malarstwa, rzeźby, sprzęty liturgiczne i funeralne, dopełnione nowoczesnymi metodami narracji edukacyjnej. Wieczorem, o godzinie 18, w kościele pw. Zwiastowania NMP odbyła się msza święta w intencji przewodników. Dzięki przeprowadzonej rewitalizacji mieszkańcy, turyści, pielgrzymi mogą podziwiać piękno największej barokowej świątyni w przedrozbiorowej Rzeczypospolitej.

Słowa kluczowe: Zamość; kościół Franciszkanów; rewitalizacja; Akademia Zamojska 